\title{
Engaging with Human Identity in Social- Ecological Systems: A Dialectical Approach
}

\author{
Micah Ingalls and Richard Stedman \\ Department of Natural Resources \\ Cornell University, Ithaca, United States
}

\section{Abstract}

Vexing problems of global environmental change call for better conceptual and analytical approaches for understanding human behaviors, factors influencing these behaviors, and the causal pathways through which these shape social and environmental outcomes. While human identity meanings provide key analytic objects in the interrogation of these dynamics, identity-based research has been truncated by a historic overemphasis on social factors and a lack of critical engagement with the ecological context of these processes.

Adapting Giddens's concept of structuration, we draw on recent advances in socialecological systems scholarship and human structural ecology to propose a new conceptual approach for understanding human identity processes and their relation to social-ecological structure. Resituating the human person within complex socialecological systems, we suggest some causal pathways through which ecological (in addition to social) elements are active in the emergence of human identity and, conversely, the ways in which identity-based behaviors interact dialectically with social-ecological structure to produce outcomes significant along both social and ecological dimensions. Finally, we explore some implications of this reframing for the interrogation of society-nature dynamics and for empirical research engaging with social-ecological change and resilience.

Keywords: identity, social-ecological systems, structural human ecology, structuration

\section{Introduction}

The dominance of human influence on environmental processes calls for better conceptual and analytical tools for understanding how human behaviors emerge and the pathways through which these interact with and shape environmental

1 Corresponding author: mli6@cornell.edu 
outcomes. Fundamental to human behavior are questions of identity-the ways in which people understand who they are, their role in society, and their relation to their broader environment. Systematic analysis of the processes of identity formation and maintenance- and the social origins and consequences of these processessparked rich debate throughout the twentieth century beginning with the work of Mead (1934) and Blumer (1986) on symbolic interactionism and, later, related work on structural identity theory by Stryker (1994), Stryker and Burke (2000) and others. Within these discourses, interrogation of the causal mechanisms by which human identities are formed, elaborated, and verified within social structure have produced important insights into human behaviors and how these intersect with social institutions. We are here primarily concerned with the behavioral manifestations of these self-held meanings and values-how they shape the practical engagement of the human person within real-world systems-and so we refer to Archer's (2000) definition of identity as the "constellation of commitments" that comprise the individual self, resulting from the individual's interaction with society and the numerous negotiations by which identity meanings are hammered out. The transactional relationship through which these identity meanings are formed, maintained, and modified may be understood to occur through symbolic exchanges in which behaviors, discourses, and symbols become normative and are given social value. In this way, the performance of identity through symbolically meaningfuland normatively consistent-behaviors enables the individual to create and verify his or her identity through interactions with others (Blumer, 1969; Burton et al., 2008). For example, role-based identities of farmer, wife, husband, doctor, patriot, and so forth all carry with them sets of normative behaviors that will vary-in form, strength, or salience-according to the identity in question and the context in which it is performed (Burke \& Stets, 2009). Contemporary identity theory has spent a fair amount of time elaborating the relationship between identity and identity performance through interactive social relationships (such as through the successful performance of role-based interactions between teacher and student, parent and child, or husband and wife, as evaluated by successfully embodying these roles exhibited through appropriate behaviors). The performance of these normative behaviors is the social mechanism by which individuals demonstrate their identity, not only as a teacher (for example) but as a good teacher. In this way, the performance of these identity-based behaviors takes on a symbolic dimension, and the performance of identity through symbolic exchanges constitutes the basis of interactional identity theory (Blumer, 1969; McCall \& Simmons, 1978).

The content of these normative behaviors and their attributed symbolic value in identity processes are, of course, fluid and continually modified through identity performance and symbolic transaction. While these dynamic processes may operate dyadically (between individuals), they also take place between the individual and the broader structure of society-its institutions, norms, and so on - within which the individual operates. Giddens's (1984) work on structuration has been particularly 
influential here in helping to conceptualize the ways in which the performance of human identity derives from, but also shapes, structure. Structuration suggests that the individual human agency operates in constant dialectical interaction with social structure. The individual selects (consciously or unconsciously) from among a possible range of identity meanings, values, and socially significant symbolic and normative behaviors. These selections are constrained by social forces that privilege some elements more than others, guiding the formation of individual human identities. The individual, while not fully free, nevertheless retains a degree of agency, variously reproducing, rejecting, and negotiating the influences of this broader social structure. Insofar as existing identity categories and meanings are taken up by the individual and inform the performance of their identity through normative behaviors, the individual functions to reproduce social structure. Where the individual rejects or modifies these identity categories, their content, or the set of available normative behaviors, we begin to see the interplay between agency and social structure (such as where an individual contests that "being a good daughter" must necessarily entail certain sets of given behaviors). While these agential responses may not persist, or may be resisted in society, there are times when they are taken up by others in society and may act back against structure and modify it (such as where broader sections of society might seek to redefine the filial duties of a daughter to her parents). Through this dialectical interaction between structure and agency both are continually produced, reproduced, and modified, and thus are mutually constituted.

Although identity scholars have differed in their relative emphases on social structure versus agency, or the mechanisms by which meanings are socially constructed and how these constructions function in identity processes, there is general agreement that the primary, perhaps exclusive, modes of exchange are situated within the realm of social interaction. Whether, how, and to what degree the biophysical or ecological setting of human action in general—and the character of specific settings in particular-are also operative in the identity processes remains an open debate; the relevance of environmental variables, even where not openly rejected, remain implicit and underexplored (Krogman \& Darlington, 1996). Burke and Stets (2009), for example, acknowledge that biophysical elements provide resources and physical settings for the functioning of systems of interaction but seem to uncritically lump these elements together under the rubric of social structure, implying that ecological and social elements are functionally indistinguishable in identity formation and maintenance processes. Neglecting to differentiate between the social and ecological components of structure and the various processes that each is subject to necessarily hinders the interrogation of their differential influences on, and responses to, human identity processes (Weigert, 1991). Furthermore, casting environmental elements in overly socialized terms has kept identity theory largely isolated from parallel discussions on the human dimensions of ecological change, furthering the historical rift between the social and biophysical sciences (Freudenburg et al., 1995; Hawley, 1944). 
Theoretical advances in two closely related sets of literature-social-ecological systems scholarship and work on structural human ecology (the latter dealing with questions of structure and agency within human-ecological systems; see Dietz \& Jorgenson, 2016) — have provided potentially useful conceptual approaches for understanding complex interactions between social and ecological processes that may be usefully employed to revisit the potential role(s) played by ecological elements within human identity research (Dietz \& Jorgenson, 2016). Social-ecological systems thinking conceives of social and ecological elements-involving socioeconomic and political as well as biophysical, geochemical, and climatic elements among others- as conjoined and interacting, rather than analytically or functionally separate. Such approaches emphasize, for example, feedback processes between social and ecological events and signals (Folke, 2006) and interscalar interactions between larger, macrostructural processes and smaller, nested cycles (Cash et al., 2006) to understand how these interactions function to shape system complexity and the ability of these systems to negotiate change pathways through time (Carpenter and Folke, 2006). While these conceptualizations of social-ecological coupling have furthered our understanding of complex systems, advances have come about imperfectly and unevenly, arguably privileging ecological processes and insights while not doing due diligence with regard to social elements and processes (Duit et al., 2010). Critics point to the underdeveloped incorporation of key concepts of human ontology and thus its insufficient engagement with values, interpersonal commitments, and the role played by human agency in shaping system outcomes (Stedman, 2016). For example, while resilience scholarship emphasizes surprise and nonlinearity in system functions, it tends to attribute these to the emergent properties of complex, multiscalar drivers and interactions that are-or assumed to be-generally deterministic (Davidson, 2010). While we suggest that this critique may be an overgeneralization and that recent scholarship has begun a more socially informed engagement with human elements in social-ecological systems (e.g., Berkes \& Ross, 2013; Burns \& Rudel, 2015; Ingalls \& Stedman, 2016; Marshall, 2010; Marshall \& Marshall, 2007), resilience thinking nevertheless retains some simplifying assumptions with regard to the myriad commitments, motivations, and values that guide human decisionmaking or the staggering capacity of human agency to shape not only the impacts of change drivers but also the nature of the drivers themselves (McLaughlin \& Dietz, 2008). We suggest that the exploration of how human identity processes articulate with social-ecological systems may provide useful insights both for a historically oversocialized human identity theory and for potentially overecologized complex systems' scholarship.

In this paper we suggest a new conceptual approach for interrogating the role(s) of human identity processes in negotiating environmental change, and for exploring the ways in which these processes play out across social and ecological domains within complex systems. We advance a more ecologically informed engagement with identity theory and demonstrate how identity processes interact with 
ecological system elements and produce material outcomes in real-world socialecological systems. Our purpose, therefore, is twofold: (1) to overcome identity theory's overly socialized framework by inserting a more ecologically conscious approach and (2) to demonstrate that identity processes represent a set of important and commonly overlooked cognitive and behavioral linkages between social and ecological system elements. Accomplishing this twin purpose involves exploring some of the ways in which ecological elements play an active role in identity processes that, in turn, function to mediate diverse social processes which impact ecological system components. We build this case in the following fashion: In the first section, we explore some ways in which the ecological elements and processes form important components in the structure within which human identity operates, playing an important role in shaping the emergence of particular identities by setting parameters around the range of human experiences in particular places and thus the symbolic meanings that can be supported. In the second section, we will engage with how the performance of human identities through normative behaviors has not only symbolic, but also real-world consequences for the ecological as well as social elements of structure.

\section{Social-ecological structure and the formation of human identity}

In order to conceptualize how the social-ecological system participates in the construction of human identity, we must resituate the individual person within a broader conceptualization of the human person as both a social and corporeal (ecological) being. Identity processes, while also social, are negotiated by the embodied individual who operates within a real world "that is there" that includes not only symbolic elements but also material ones (Mead, 1934) that impinge upon the human person in different but closely interrelated ways. The impacts of ecological elements that shape human identities are felt both as direct biophysical prompts as well as those higher-order place meanings that are shaped through the lens of social experience, construction, and associated normative demands. This suggests two closely interrelated pathways by which biophysical or ecological elements of the environment are formative in the development and maintenance of human identities, each depending (albeit in different ways) upon the particular character of the environment.

The first of these pathways deals with the mode of interaction between the human as biological organism and the environment within which it lives, moves, and seeks to secure its existence. The biophysical character of the particular environment circumscribes possible modes of engagement by variously fostering and inhibiting particular human behaviors. At the most basic level, the ecological and material world impinges on the individual through physical prompts and sensory cues, such 
as gravity, weather, edibility (Archer, 2000), perceptual constraints (Cheng et al., 2003; Tuan, 1974), and evolutionarily derived psychological cues (Kellert \& Wilson, 1993). These environmental (and other) prompts attain the status of what Durkheim (1982) refers to as the "morphological facts" underpinning social functions, forming a structure that favors certain forms of engagement, constrains others, and thereby shapes the nature of routine behaviors associated with (for example) procuring food, shelter, and the other fundamental necessities (what Bourdieu, 1998, refers to as the habitus of the individual). This day-to-day engagement with the material world has, for most of human history, occupied the majority of humanity's time and attention and plays an important role in shaping those self-definitions that are salient in the formation of identity (Clayton \& Opotow, 2003).

These physical and ecological constraints on, and enablers of, human behaviors provide an important pathway by which ecological system elements begin to actively shape what sorts of self-held meanings are hindered or facilitated within particular environments (Archer, 2000; Sack, 1997; Stedman 2003). To take a simple (if extreme) example, an individual may much more easily identify as a fisherwoman/ man in a coastal environment than in a desert. While this primary pathway might be said to represent the most direct relationship between the individual and his or her biophysical environment, the social and ecological elements are inextricable, and continually interpenetrating (Freudenburg et al., 1995), problematizing a direct or unmediated causal interaction (a mistake made by environmental determinism; see Peet, 1985). The attributes of the physical or ecological environment that impinge directly on the human person are thus also mediated through social structure in important ways. The environmental constraints and enablers of agricultural production, for example-influencing what sorts of agriculture, and thus what sorts of farmers are probable, or even possible, within particular landscapes-are also shaped by the interplay of the physical environment with available technologies, transportation networks, and market forces that may extend (or limit) the range of ecologically possible modes of engagement (see, e.g., Hedrick, 1966; Lobao \& Meyer, 2001; Moran, 2011).

While biophysical prompts are certainly most accessible to the individual through sensory perception and inhabitation in the material world, they accumulate at higher social levels to produce emergent social responses to environmental conditions. This suggests a second pathway by which the biophysical elements of environment help to form human identity: through the way in which the environment shapes the social construction of landscape meanings and the normative implications of those meanings (Sack, 1997; Stedman, 2003; Stokowski, 2002; Tuan, 1974). For example, dramatic landscape features such as soaring mountain ranges or deep canyons facilitate some kinds of human uses more than others but also give rise to particular labels and associated institutional management and regulationfor example, as national parks (Runte, 2007)— that permit or prohibit different 
uses and associated meanings by virtue of these designations. Society's collective engagement within and between particular environments interacts with other social forces to code meanings onto the physical landscape and, thus, to socially construct it. Greider and Garkovich (1994, p. 1) nicely articulate the significance of this attribution of symbolic meaning which provides a lens through which the individual views the meanings and significance of their landscape. They write, "the real estate developer, the farmer, the hunter are definitions of who people are, and the natural environment - the physical entity of the open field-is transformed symbolically to reflect these self-definitions." What is especially significant about the social construction of the landscape is not only that it shapes perception but also that it represents, in a very real way, a system of encoded norms for those who inhabit those landscapes (Massey, 1994). "This is farm country" is not only a descriptive statement characterizing the setting and the identity of people within the landscape, but also a prescriptive statement regarding what sort of activities and behaviors are normatively "in place" (versus “out of place," Sack, 1997; see also Cresswell, 1996). These "rule-embedded landscapes" play a direct role then in shaping the identity of persons within them by variously proscribing and prescribing particular behaviors and by socially constraining the suite of possible identities available to individuals within those landscapes.

Notwithstanding the important role that this social construction of nature plays in the formation of these meanings and shaping of human perceptions, it is worth noting here-pursuant to the principal thrust of this paper-that the social constructionist perspective has tended to go too far in its emphasis on these constructions, undervaluing their ecological basis (Stedman, 2003). For example, Greider and Garkovich write, "of course humans reside in a natural 'world that is there,' but this world is meaningless" (1994, p. 2, emphasis ours), neglecting the possibility that this natural world plays an active role in shaping the meanings that are brought to it. They write, further, "the open field is the same physical thing, but it carries multiple symbolic meanings that emanate from the values by which people define themselves" (1994, p. 1). While this is clearly the case, it is equally clear that there are limits to the range of possible meanings. It makes a great deal of difference that the open field is an open field and not a forest and, further, that it is a particular kind of field with specifiable material properties of soil, slope, drainage, view, and others - all of which bracket the range of its possible uses and the attributed meanings it can hold: simply put, these features rule out altogether some uses or meanings, impede some, and facilitate others. To whatever degree theory has presented us with an overly socialized framing of these constructions it has led us away from the possibility of recognizing — and thus analytically engaging with - the very real biophysical and ecological elements which set the boundaries for those constructed meanings. We cautiously suggest that the social constructivists have often been unable to see the (material) forest for the construction of their trees. 
We advance here an alternative framing of the social construction of landscape meanings that situates social construction within real biophysical spaces. Attributed meanings must be constructed in reference to the content of the particular landscape, the character of which allows only a limited set of possible meanings and, moreover, lends itself more readily to some of those meanings than to others. We also highlight possible indirect effects: the material reality provides the grounding for subsequent socially structured elements (e.g., lakeside resorts rather than industrial facilities) that further shape these experiences and meanings.

Let us consider two examples that might illustrate the ways in which ecological parameters shape human identities both through the biotic prompts of the environment as well as the social meanings attributed to particular ecological environments. Modes of agricultural production in the United States have changed considerably since the late nineteenth century, due to technological advances in productive practices and transportation networks, national agricultural policies, and the opening of large areas of the American Midwest (Lobao \& Meyer, 2001). Agricultural changes that have resulted in increasingly large farm parcels utilizing a limited number of cultivars have played an important role in shaping what it means to be an American farmer (Albrecht \& Murdock, 1984). The central importance of producing commodities for largely nonlocal markets, and the economies-ofscale advantages afforded to conglomerate farms have resulted in increasingly large operations managed by an ever-decreasing number of individuals. These structural changes have fostered the emergence of productivist farmer identity types, whose self-held conceptions of what it means to be a farmer emphasize commodity production (especially emphasizing staple food products) and economic efficiency (Fitchen, 1991; see also similar examples from Europe-Burton et al., 2008; Burton $\&$ Wilson, 2006).

While these agricultural changes are clearly social phenomena, their patterning across the landscape has also been shaped by ecological parameters. In the American agricultural experience the flat, relatively unvaried, deep and fertile topsoils of the Midwestern plains have allowed for parcel conglomeration and the mechanization of field crop production that could not have occurred elsewhere to nearly the same degree (Lobao \& Meyer, 2001). By contrast, the shallow soils of the northeastern United States have limited the productivity (especially in comparative terms) of commercial grain and other commodity harvests (Bills, 2001; Hedrick, 1966), while the heterogeneity of its landscapes has inhibited parcel conglomeration, presenting economies-of-scale disadvantages (Andersen, 1932; Bills, 1990). In these areas, productivist farmer identities have become increasingly strained due to the interactive effects of agricultural restructuring and biophysical conditions (Fitchen, 1991; Ingalls, 2012). 
The "Northwoods" area of Wisconsin provides a second example. Once heavily forested with evergreen trees with important biophysical properties (they floated well and were thus able to be moved to downstate processing facilities via the abundant river network in the region-yet another ecological reality that shaped development; Fries, 1989), these areas were cleared during the late nineteenth century, leaving behind poor soils and few livelihood alternatives. While the government of Wisconsin actively promoted agriculture in that area to support development and local economy (Carstensen, 1958), these efforts ultimately proved unsuccessful (Williams \& Van Patten, 2006) largely because of the poor soils which would not support agricultural land uses (Gough, 1997) and harsh winters that limited growing seasons. The failure of agriculture to establish in this area allowed for the reforestation of the landscape. This is coupled with the incredible abundance of surface-water resources (north-central Wisconsin contains one of the richest densities of lakes in the world; Attig, 1984; Magnuson et al., 2006) that fostered the growth of a substantial tourism sector for people seeking "escape" and natural environments. These forested and lake-rich landscapes, rather than their agricultural alternative (which could not be so readily supported by the ecological conditions of the system), have in recent decades seen the rapid proliferation of second homes and other residential developments (Green et al., 2005; Schewe et al., 2012). Amenityrich areas such as these that offer mountains, lakeshores, coastlines, and forests are commonly chosen for the siting of second homes. Remoteness from modern society, a sense of being in nature, and ideals of simplicity and space for pause and reflection all figure prominently as motivations for second home development in these landscapes (Stedman, 2006). By removing themselves from the demands of modern life-in which many people emphasize their inability to express self-held meanings which they consider core to their identity-and resituating themselves in these "natural places," individuals are given greater freedom and scope for the elaboration and expression of these core values (Williams \& Van Patten, 2006).

What is important for our purposes here is that self-held meanings and identities are created and reinforced in these areas in part due to the particularistic ecological character of the landscapes. While the constructed meanings of these places are clearly social, those meanings depend upon certain kinds of social experiences that are enabled by the particular biophysical elements in the landscape, all of which change through time.

These pathways represent two possible ways in which the ecological elements of the social-ecological system shape human identities: While the biophysical prompts of the environment shape what sorts of behaviors are possible or enabled in those contexts, the social construction of those landscapes — and the sets of social institutions that arise in response-affects what sorts of behaviors are appropriate or expected (even legal) in those places and functions to support a particular range of identities. 
By shaping particular behaviors, and allowing for the attribution of particular social meaning to those behaviors, these processes play a role in directing the formation of the values and self-held meanings of the individuals.

\section{The performance of identity in social-ecological systems}

In the section above, we dealt with some ways in which ecological elementsas a necessary counterpart to social elements in broader structure-may function to shape human identity processes. In what follows, we will consider the inverse of this relationship, looking at how the performance of human identities acts back upon the environment to shape social-ecological systems and change.

While there is clearly a symbolic dimension to human behaviors that results from identity-based commitments and self-perceptions, these behaviors are not only symbolic, they are also practical actions in a world of real material objects (Archer, 2000) and thus their performance has material implications for ecological (as well as social) system elements. Any human activity that entails practical engagement with the ecological world will inevitably effect change on that world. While this direct causal relationship between human activities and the elements and processes of the biophysical world is self-apparent, what has been less obviousor rather, what has been obfuscated in identity discourse because of a systematic privileging of social interaction over other forms of exchange-is how the performance of identity affects these ecological elements and processes.

To return to the example of the agricultural productivist identity type, wherein primary commitments prioritize maximizing commodity production in the service of profit (versus, say, placing a primary value on the nonproductive aspects of farm land, such as habitat management), the performance of these identity meanings entails particular modes of agricultural practice that maximize productivity and economic efficiency and thereby verify productivist identity meanings to themselves and to others who share similar understandings and hold similar self-definitions of what it means to be a farmer (Burton \& Wilson, 2006; Goldschmidt, 1978). Agricultural behaviors consistent with productivist farmer identities may include large-scale monocultures, intensive nutrient management through inorganic fertilizers, chemical-based pest management regimes, and the cultivation of all available lands within the farm for the purpose of maximizing agricultural productivity and, in so doing, verify the farmer's identity claims. While the successful performance of these behaviors has social and symbolic value (that is, these done well signify the farmer as a "good farmer"), ecological impacts are equally significant. These include impacts on soil conservation and erosion, floral and faunal biodiversity within monocultural fields, cultivar diversity (possibly reduced due to a focus on high-producing or 
genetically modified varieties), pesticide impacts in fields and nontarget habitats, and nitrogen and phosphorous loading in surface water and groundwater (see, e.g., Altieri, 1999; Matson et al., 1997). While economic motivations for these agricultural practices are important, they often persist despite strong economic disincentives or countervailing social pressures that would otherwise prompt behavior change (Burton \& Wilson, 2006; Fitchen, 1991; Ingalls, 2012).

While the relationship between identity performance and the impacts of that performance on social-ecological structure may be more apparent in the case of productive natural resource-based occupational identities (as in the agricultural examples above), the performance of nonproductive (consumptive) identities also impacts directly on the biophysical elements of the landscape. In our earlier example-that of second home and residential development within highamenity areas in the Northwoods of Wisconsin-we observed that people locate to particular areas (whether seasonally or permanently), which they perceive as being able to support their own self-definitions. These movements themselvespurposive relocation to landscapes which support these core values of identityrepresent one aspect of the performance of these identities and have a direct impact on the biophysical elements of these landscapes, affecting ecosystem processes in numerous ways (Hall \& Müller, 2004). The forests and lakes of this landscape, and the experiences offered there, contribute mightily to the "up north escape" identity of the landscape (Stedman, 2000) and those using it. We need to ask, however, how the behaviors associated with the performance of these place-based identities in turn reshape the character of the landscape. The region has seen rapid development of second homes, especially around lakes, with resultant increased population density (Carpenter et al., 2007; Gonzalez-Abraham et al., 2007). This in turn has led to great concern about the impacts of increased development and indices of potential disturbance (Racey \& Euler, 1983). While concerns have been raised about the effects of development on lakeshore flora (Clark \& Euler, 1984; Dwyer \& Childs, 2004) and fauna (Clark et al., 1984), probably the strongest voices have been around effects of increased development on water quality (e.g., Dillon et al., 1994; Hendry \& Leggatt, 1982), leading to discussion of potential policy actions (e.g., Meyer et al., 1997; WDNR, 1996). A more subtle form of action is at work here as well. The emphasis on the recreational "escape," "up north" identities also has the potential to crowd out alternative identities — such as those based on livelihoods - asserting that some meanings and associated development (e.g., those tied to recreation) better "fit" the landscape (Creswell, 1996). This possibility has led to lively debates about scenarios for the future of the region (e.g., Peterson et al., 2003).

The effects of identity performance on social-ecological structure result not only from the actions of individuals but also from the social institutions that emerge from, and are supported or contested by, these self-held commitments. We noted this previously when dealing with the normative outcomes of the social construction 
of landscapes but revisit it here to point out that these normative valuations are not only the product of social-ecological structural elements but also the outcome of individual and collective identity-based commitments that compete within an uneven playing field. Some socially constructed meanings attain normative status and form the logics of social institutions and normative place-claims, while other claims are marginalized (see, e.g., Castree, 2004; Massey 1994). These meaningsemergent from the interactive and power-filled relations between social-ecological structure and individual and collective identity commitments—act back again on the social-ecological system with material outcomes in ecological as well as social processes.

\section{Conclusion: Identity and social-ecological structure in dialectic}

In the sections above, and for the purpose of building our argument, we have artificially teased apart the emergent and interactive relational processes between social-ecological structure and human identity. In closing, we bring these back together and suggest a reformulation of Giddens's (1984) concept of structuration that recognizes the ineluctability of both social and ecological elements. This may provide a more productive way forward as we explore the implications of human identity processes within real-world systems. Such a (re)formulation allows us to accomplish two objectives: in the first place, it resituates ecological system elements as important forces in the formation of human identity meanings while, in the second place, it may provide new explanatory variables in the interrogation of the ways in which the performance of human identity is not only socially significant but also results in real-world environmental outcomes, and that the two of these are structurally interrelated in human-ecological systems. Invoking the language of structuration-suggesting a more ecologically informed reconceptualization, perhaps "social-ecological structuration"-we describe the social-ecological elements of the system as shaping, influencing, constraining, and enabling-but not determining-leaving room for the powers of human agency as the individual innovates, imagines, and modifies their behavior in response to these structural social-ecological elements and processes and, through this agential action, shapes and modifies the system. Human agency thus emerges as an element in the system that derives, in part at least, from sets of self-held beliefs, commitments, and selfperceptions. Such a framing articulates well both with the coupled-systems approach to understand complex system functions and with approaches to understanding the dialectical relation between individuals and structure currently being advanced within structural human ecology (see, e.g., Dietz \& Jorgenson, 2016, and others in that issue). 
While we have here focused our attention on building the conceptual apparatus for cross-walking between identity theory and coupled-systems approaches to understanding nature-society relations, we have not yet made explicit the linkage between the functions of identity processes within social-ecological systems and how these processes condition the resilience of these systems to change- a dominant interest in coupled-systems scholarship. The scope for developing this link is, we suggest, far reaching, important, and currently underdeveloped within resilience science. Signals of ecological disturbance and change, for example, are interpreted and mediated not only through scientific, economic, or other lenses but also through the filters of individual perception with regard to the symbolic and psychosocial import of these changes. Threats to place-based meanings brought about by social and ecological changes, for example, have been posited to instigate agential action to combat these threats (Stedman, 2002), suggesting an important identity-based feedback process that may play a role in resilience.

More work remains to be done in exploring the empirical basis-and myriad empirical manifestations_ - of the relationship between identity processes and socialecological system functioning and resilience, and in elaborating specific causal mechanisms linking these. We anticipate that further exploration of the mechanisms and processes of identity formation in the exchange between human individuals and social-ecological contexts will yield promising new ways of analyzing complex structural change and, we hope, foster creative interaction between disparate streams of theory which run through the social sciences on one hand and the biophysical sciences on the other.

\section{References}

Albrecht, D. E., \& Murdock, S. H. (1984). The sociology of U.S. agriculture: An ecological perspective. Ames, IA: Iowa State University Press.

Altieri, M. (1999). The ecological role of biodiversity in agroecosystems. Agriculture, Ecosystems and the Environment, 74(1-3), 19-31. doi.org/10.1016/S0167-8809 (99)00028-6

Andersen, R. H. (1932). New York agriculture meets the West: 1830-1850. The Wisconsin Magazine of History, 16(2), 163-198.

Archer, M. S. (2000). Being human: The problem of agency. Cambridge, UK: Cambridge University Press. doi.org/10.1017/CBO9780511488733

Attig, J. W., Jr. (1984). The Pleistocene geology of Vilas County, Wisconsin (Unpublished doctoral dissertation). University of Wisconsin-Madison. 
Berkes, F., \& Ross, H. (2013). Community resilience: Towards an integrated approach. Society \& Natural Resources, 26(1), 5-20. doi.org/10.1080/0894192 0.2012 .736605

Bills, N. L. (1990). Land use in rural New York-Agriculture or development? New York's Food and Life Science Quarterly, 20(1/2), 8-11.

Bills, N. L. (2001). Agriculture-based economic development: Trends and prospects for New York (Extension Bulletin 2001-18). Ithaca, NY: Cornell University, Department of Applied Economics and Management.

Blumer, H. (1969). Symbolic interactionism: Perspective and method. Englewood Cliffs, NJ: Prentice-Hall.

Blumer, H. (1986). Symbolic interactionism: Perspective and method. Berkeley, CA: University of California Press.

Bourdieu, P. (1998). Practical reason: On the theory of action. Stanford, CA: Stanford University Press.

Burke, P. J., \& Stets, J. E. (2009). Identity theory. New York, NY: Oxford University Press. doi.org/10.1093/acprof:oso/9780195388275.001.0001

Burns, T. J., \& Rudel, T. K. (2015). Metatheorizing structural human ecology at the dawn of the third millennium. Human Ecology Review, 22(1), 13.

Burton, R. J. F., Kuczera, C., \& Schwarz, G. (2008). Exploring farmers' cultural resistance to voluntary agri-environmental schemes. Sociologia Ruralis, 48(1), 16-37. doi.org/10.1111/j.1467-9523.2008.00452.x

Burton, R. J. F., \& Wilson, G. A. (2006). Injecting social psychology theory into conceptualizations of agricultural agency: Towards a post-productivist farmer self-identity? Journal of Rural Studies, 22, 95-115. doi.org/10.1016/j. jrurstud.2005.07.004

Carpenter, S. R., Benson, B. J., Biggs, R., Chipman, J. W., Foley, J. A., Golding, S. A., ... Kratz, T. K. (2007). Understanding regional change: A comparison of two lake districts. Bioscience, 57(4), 323-335. doi.org/10.1641/B570407

Carpenter, S. R., \& Folke, C. (2006). Ecology for transformation. Trends in Ecology and Evolution, 21(6), 309-315. doi.org/10.1016/j.tree.2006.02.007

Carstensen, V. R. (1958). Farms or forests: Evolution of a state land policy for northern Wisconsin, 1850-1932. Madison, WI: University of Wisconsin. 
Cash, D. W., Adger, W. N., Berkes, F., Garden, P., Lebel, L., Olsson, P., ... Young, O. (2006). Scale and cross-scale dynamics: Governance and information in a multilevel world. Ecology and Society, 11(2), 8. doi.org/10.5751/ES-01759110208

Castree, N. (2004). Differential geographies: Place, indigenous rights and "local" resources. Political Geography, 23(2), 133-167. doi.org/10.1016/j.polgeo. 2003.09.010

Cheng, A. S., Kruger, L. E., \& Daniels, S. E. (2003). "Place” as an integrating concept in natural resource politics: Propositions for a social science research agenda. Society and Natural Resources, 16(2), 87-104. doi.org/10.1080/08941920309199

Clark, K. L., \& Euler, D. L. (1984). Vegetation disturbance caused by cottage development in central Ontario. Journal of Environmental Management, 18, 229-239.

Clark, K. L., Euler, D. L., \& Armstrong, E. (1984). Predicting avian community response to lakeshore cottage development. Journal of Wildlife Management, 48(4), 1239-1247. doi.org/10.2307/3801784

Clayton, S., \& Opotow, S. (2003). Identity and the natural environment. Cambridge, MA: MIT Press.

Cresswell, T. (1996). In placelout of place: Geography, ideology, and transgression. Minneapolis, MN: University of Minnesota Press.

Davidson, D. J. (2010). The applicability of the concept of resilience to social systems: Some sources of optimism and nagging doubts. Society and Natural Resources, 23(12), 1135-1149. doi.org/10.1080/08941921003652940

Dietz, T., \& Jorgenson, A. K. (2016). Introduction: Progress in structural human ecology. Human Ecology Review, 22(1), 3.

Dillon, P. J., Scheider, W. A., Reid, R. A., \& Jeffries, D. S. (1994). Lakeshore capacity study: Part I. Test of effects of shoreline development on the trophic status of lakes. Lake and Reservoir Management, 8, 121-129. doi.org/ $10.1080 / 07438149409354464$

Duit, A., Galaz, V., Eckerberg, K., \& Ebbesson, J. (2010). Governance, complexity, and resilience. Global Environmental Change, 20(3), 363-368. doi.org/10.1016/j. gloenvcha.2010.04.006

Durkheim, E. (1982). The rules of sociological method. New York, NY: Free Press. doi.org/10.1007/978-1-349-16939-9 
Dwyer, J. F., \& Childs, G. M. (2004). Movement of people across the landscape: A blurring of distinctions between areas, interests, and issues affecting natural resource management. Landscape and Urban Planning, 69(2-3), 153-164. doi.org/10.1016/j.landurbplan.2003.09.004

Fitchen, J. M. (1991). Endangered spaces, enduring places: Change, identity and survival in rural America. Boulder, CO: Westview Press.

Folke, C. (2006). Resilience: The emergence of a perspective for social-ecological systems analyses. Global Environmental Change, 16(3), 253-267. doi.org/ 10.1016/j.gloenvcha.2006.04.002

Freudenburg, W. R., Frickel, S., \& Gramling, R. (1995). Beyond the nature/society divide: Learning to think about a mountain. Sociological Forum, 10(3), 361-392. doi.org/10.1007/BF02095827

Fries, R. F. (1989). Empire in pine: The story of lumbering in Wisconsin, 1830-1900 (Rev. ed.). William Caxton Ltd.

Giddens, A. (1984). The constitution of society. Cambridge, UK: Polity Press.

Goldschmidt, W. (1978). As you sow: Three studies in the social consequences of agribusiness. Montclair, NJ: Allanheld and Osmun.

Gonzalez-Abraham, C. E., Radeloff, V. C., Hammer, R. B., Hawbaker, T. J., Stewart, S. I., \& Clayton, M. K. (2007). Building patterns and landscape fragmentation in northern Wisconsin, USA. Landscape Ecology, 22(2), 217-230. doi.org/10.1007/s10980-006-9016-z

Gough, R. (1997). Farming the cutover: A social history of Wisconsin 1900-1940. Lawrence, KS: University Press of Kansas.

Green, G. P., Deller, S. C., \& Marcouiller, D. W. (Eds.). (2005). Amenities and rural development: Theory, methods and public policy. Cheltenham, UK: Edward Elgar Publishing. doi.org/10.4337/9781845428075

Greider, T., \& Garkovich, L. (1994). Landscapes: The social construction of nature and the environment. Rural Sociology, 59(1), 1-24. doi.org/10.1111/j.15490831.1994.tb00519.x

Hall, C. M., \& Müller, D. K. (2004). Tourism, mobility and second homes: Between elite landscapes and common ground. Clevedon, UK: Channel View Publications.

Hawley, A. H. (1944). Ecology and human ecology. Social Forces, 398-405. doi.org/10.2307/2571805 
Hedrick, U. P. (1966). A history of agriculture in the State of New York (Reprint ed.). New York, NY: New York State Agricultural Society.

Hendry, G. S., \& Leggatt, E. A. (1982). Some effects of shoreline cottage development on lake bacteriological water quality. Water Resources, 16, 1217-1222. doi.org/10.1016/0043-1354(82)90140-3

Ingalls, M. (2012). Why the hyphen matters: Diversity in farmer identity across a transitional landscape (Unpublished Master's thesis). Cornell University, Ithaca, NY.

Ingalls, M. L., \& Stedman, R. C. (2016). The power problematic: Exploring the uncertain terrains of political ecology and the resilience framework. Ecology and Society, 21(1), 6. doi.org/10.5751/ES-08124-210106

Kellert, S. R., \& Wilson, E. O. (Eds.). (1993). The biophilia hypothesis. Washington, DC: Island Press.

Krogman, N. T., \& Darlington, J. D. (1996). Sociology and the environment: An analysis of journal coverage. The American Sociologist, 27(3), 39-55. doi.org/10.1007/BF02692039

Lobao, L., \& Meyer, K. (2001). The great agricultural transition: Crisis, change, and social consequences of twentieth century US farming. Annual Review of Sociology, 27, 103-124. doi.org/10.1146/annurev.soc.27.1.103

Magnuson, J. J., Kratz, T. K., \& Benson, B. J. (Eds.). (2006). Long-term dynamics of lakes in the landscape. Oxford, UK: Oxford University Press.

Marshall, N. A. (2010). Understanding social resilience to climate variability in primary enterprises and industries. Global Environmental Change, 20, 36-43. doi.org/10.1016/j.gloenvcha.2009.10.003

Marshall, N. A., \& Marshall, P. A. (2007). Conceptualizing and operationalizing social resilience within commercial fisheries in northern Australia. Ecology and Society, 12(1), 1. doi.org/10.5751/ES-01940-120101

Massey, D. (1994). Space, place and gender. Minneapolis, MN: University of Minnesota Press.

Matson, P. A., Parton, W. J., Power, A. G., \& Swift, M. J. (1997). Agricultural intensification and ecosystem properties. Science, 277(5325), 504-509. doi.org/10.1126/science.277.5325.504

McCall, G., \& Simmons, J. L. (1978). Identities and interactions (Rev. ed.). New York, NY: Free Press. 
McLaughlin, P., \& Dietz, T. (2008). Structure, agency and environment: Toward an integrated perspective on vulnerability. Global Environmental Change, 18(1), 99-111. doi.org/10.1016/j.gloenvcha.2007.05.003

Mead, G. H. (1934). Mind, self, and society. Chicago, IL: University of Chicago Press.

Meyer, M., Woodford, J., Gillum, S., \& Daulton, T. (1997). Shoreland zoning regulations do not adequately protect wildlife habitat in northern Wisconsin (US Fish and Wildlife Service State Partnership Grant P1W, Segment 17, Final Report). Madison, WI.

Moran, E. F. (2011). Environmental social science: Human-environment interactions and sustainability. Chichester, UK: Wiley-Blackwell.

Peet, R. (1985). The social origins of environmental determinism. Annals of the Association of American Geographers, 75(3), 309-333. doi.org/10.1111/j.14678306.1985.tb00069.x

Peterson, G. D., Beard, T. D., Jr., Beisner, B. E., Bennett, E. M., Carpenter, S. R., Cumming, G. S., ... Havlicek, T. D. (2003). Assessing future ecosystem services: A case study of the Northern Highlands Lake District, Wisconsin. Ecology and Society, 7(3), 1. doi.org/10.5751/es-00557-070301

Racey, D., \& Euler, D. (1983). An index of habitat disturbance for lakeshore cottage development. Journal of Environmental Management, 16, 173-179.

Runte, A. (2007). National parks: The American experience. Lincoln, NE: University of Nebraska Press.

Sack, R. D. (1997). Homo geographicus: A framework for action, awareness, and moral concern. Baltimore, MD: Johns Hopkins University Press.

Schewe, R., Field, D., Frosch, D., Clendenning, G., \& Jensen, D. (2012). Condos in the woods: The growth of seasonal and retirement homes in northern Wisconsin. Madison, WI: University of Wisconsin Press.

Stedman, R. C. (2000). “Up north”: A social psychology of place (Unpublished doctoral dissertation). University of Wisconsin, Madison, WI.

Stedman, R. C. (2002). Toward a social psychology of place: Predicting behavior from place-based cognitions, attitude, and identity. Environment and Behavior, 34, 405-425. doi.org/10.1177/0013916502034005001

Stedman, R. C. (2003). Is it really just a social construction? The contribution of the physical environment to sense of place. Society and Natural Resources, 16, 671-685. doi.org/10.1080/08941920309189 
Stedman, R. C. (2006). Places of escape: Second-home meanings in northern Wisconsin, USA. In N. McIntyre, D. Williams, \& K. McHugh (Eds.), Multiple dwelling and tourism: Negotiating place, home and identity (pp. 129-144). Wallingford, UK: CAB International. doi.org/10.1079/9780845931202.0129

Stedman, R. C. (2016). Subjectivity and social-ecological systems: A rigidity trap (and sense of place as a way out). Sustainability Science, 11(6), 891-901. doi.org/10.1007/s11625-016-0388-y

Stokowski, P. A. (2002). Languages of place and discourses of power: Constructing new senses of place. Journal of Leisure Research, 34(4), 368-382.

Stryker, S. (1994). Identity theory: Its development, research base and prospects. Studies in Symbolic Interaction, 16, 9-20.

Stryker, S., \& Burke, P. J. (2000). The past, present and future of an identity theory. Social Psychology Quarterly, 63(4), 284-297. doi.org/10.2307/2695840

Tuan, Y.-F. (1974). Topophilia: A study of environmental perception, attitudes, and values. Englewood Cliffs, NJ: Prentice-Hall.

WDNR (Wisconsin Department of Natural Resources). (1996). Northern Wisconsin's lakes and shorelands: A report examining a resource under pressure. WDNR.

Weigert, A. J. (1991). Transverse interaction: A pragmatic perspective on environment as other. Symbolic Interaction, 14(3), 353-363. doi.org/10.1525/ si.1991.14.3.353

Williams, D. R., \& Van Patten, S. R. (2006). Home and away? Creating identities and sustaining places in a multi-centered world. In N. McIntyre, D. Williams, \& K. McHugh (Eds.), Multiple dwelling and tourism: Negotiating place, home and identity (pp. 32-50). Wallingford, UK: CAB International. doi.org/10.1079/ 9780845931202.0032 
This text is taken from Human Ecology Review, Volume 23, Number 1, 2017, published 2017 by ANU Press, The Australian National University, Canberra, Australia.

dx.doi.org/10.22459/HER.23.01.2017.03 